\title{
Organizacja i wyniki produkcyjno-ekonomiczne gospodarstw mlecznych z następcami*
}

\section{Wstęp}

Specjalistyczna produkcja mleka wymaga zgodnego i harmonijnego współdziałania domowników. Jest najbardziej czasochłonna i najbardziej wrażliwa na jakiekolwiek zaniedbania. Dlatego powinna zasadzać się przede wszystkim na własnej sile roboczej, mimo komparatywnej przewagi Polski względem państw zachodnich w zakresie kosztów pracy najemnej.

Nieprzerwane obowiązki przy produkcji mleka mogą zniechęcać młodych rolników-następców do kontynuowania tej produkcji na rzecz specjalizacji w innej działalności, organizacyjnie bardziej ekstensywnej, dającej więcej czasu wolnego. Ważne jest, by specjalistyczne gospodarstwa mleczne nie tylko na bieżąco prawidłowo funkcjonowały, lecz by miały strategiczny cel związany $z$ doskonaleniem produkcji mleka $\mathrm{i} w$ efekcie $\mathrm{z}$ inwestowaniem. Jednak by tak się stało, muszą być w gospodarstwach następcy, i to tacy, którzy by chcieli w przyszłości pracować przy produkcji mleka. Wtedy dopiero właściciele gospodarstw widzą sens inwestowania i kreowania postępu produkcyjnego w sposób ciaggły. Jeśli jest następca, który będzie chciał pracować przy produkcji mleka, wówczas rolnik wie, że ponosi sensowny wysiłek ekonomiczny, który sprawi, że podejmowane inwestycje będą długo służyć, a dotychczasowy dorobek materialny i poznawczy zwiazzany z produkcją mleka nie pójdzie na marne.

Powyższe zagadnienie zostało zauważone $\mathrm{w}$ czasie badań nad opłacalnością produkcji mleka $\mathrm{w}$ gospodarstwach wyspecjalizowanych makroregionu środkowego. Dlatego zostało zbadane, a narzędziem stał się zaproponowany przez autora wskaźnik identyfikacji specjalistycznej następców.

W tym kontekście należy dodać, że produkcja mleka, jeśli jest prowadzona poprawnie, zwłaszcza w dużej skali, może dawać satysfakcjonujący dochód oraz z uwagi na comiesięczne wpływy zapewniać płynność finansowa gospodarstwa. Jest jednak uważana za najtrudniejsza, najbardziej skomplikowaną działalność w gospodarstwie rolniczym. Wymaga od producenta ogromnej wiedzy, cierpliwości oraz długotrwałego i emocjonalnego zaangażowania.

\footnotetext{
*Badania wykonano w ramach grantu KBN 3 P06 R 04724.
} 


\section{Cel, zakres i metoda badań}

Celem głównym badań było określenie zróżnicowania opłacalności produkcji mleka oraz próba ustalenia czynników determinujących poziom tej opłacalności.

W prezentowanych badaniach ograniczono ich zasięg. W 1996 roku w sposób celowy do badań przyjęto makroregion środkowy, obejmujący byłe województwa - łódzkie, skierniewickie, piotrkowskie, sieradzkie i płockie. Makroregion środkowy charakteryzuje się centralnym położeniem, przeciętnymi warunkami przyrodniczymi oraz zbliżoną do średniej krajowej wielkością gospodarstw.

Wybór gospodarstw do badań został dokonany jednorazowo, objęto nimi wszystkie gospodarstwa w makroregionie środkowym, które 1 stycznia $1997 \mathrm{r}$. posiadały więcej niż 10 krów mlecznych. Subiektywnie przyjęto, że producenci, którzy mają kilkanaście i więcej krów są bardziej zaangażowani w tę produkcję i są bardziej doświadczeni niż producenci mający kilka krów.

Materiał źródłowy stanowiły:

- dane statystyki masowej,

- opisy 157 badanych gospodarstw w ramach opracowanego przez autora kwestionariusza,

- karty technologiczne dla działalności roślinnych w produkcji pasz objętościowych.

W badaniu czynników różnicujących opłacalność produkcji mleka wykorzystano metody statystyki opisowej, tabelarycznej i matematycznej, w tym rachunek regresji prostoliniowej prostej i wielorakiej oraz rachunek korelacji. Zastosowano również elementy analizy kluczowych czynników sukcesu (KCS).

\section{Wskaźnik identyfikacji specjalistycznej następców}

Zagadnieniem związanym $\mathrm{z}$ siłą roboczą $\mathrm{w}$ wyspecjalizowanym gospodarstwie rolniczym jest jej jakość. Może ona wynikać nie tylko z sumienności wykonywania codziennych obowiązów czy $\mathrm{z}$ formalnie posiadanego wykształcenia rolniczego, ale zaangażowania domowników $\mathrm{w}$ daną produkcję specjalistyczną. To zaangażowanie może odzwierciedlać stan zadowolenia rodziny $\mathrm{z}$ osiagganych rezultatów ekonomicznych, rzutować na plany inwestycyjne, oczekiwania i w sumie przekładać się na ogólnie panujące podejście do tej produkcji wśród domowników. W końcowym efekcie może mieć to wyraz w naj- 
bardziej delikatnej sferze życia zawodowego rodziny rolniczej, to znaczy w postaci planów zawodowych dzieci.

Nie ulega wątpliwości, że rodzice pragną pomyślności osobistej i zawodowej swoich dzieci. Jeśli sami są zadowoleni $\mathrm{z}$ wykonywanego zawodu i prowadzonej produkcji specjalistycznej, zadowolenie to może, ale nie musi, przenosić się na dzieci. Można wstępnie przyjąć, że jeśli w gospodarstwie rolniczym jest następca $i$ wiąże on swoje plany $z$ dotychczasową produkcją, w której specjalizuje się gospodarstwo, to produkcja ta może dawać dobre rezultaty, zadowolenie i szanse na przyszłość.

Uwzględniając powyższe zagadnienie $\mathrm{z}$ zakresu organizacji specjalistycznych gospodarstw rolniczych, autor proponuje wprowadzić wskaźnik identyfikacji specjalistycznej następców (Wisn) - będący ilorazem liczebności lub udziału gospodarstw z następcami w dotychczasowej specjalizacji (Ns) do liczebności lub udziału gospodarstw z następcami ogółem (No), w wyrażeniu procentowym.

$$
\mathrm{Wisn}=\frac{\mathrm{Ns}}{\mathrm{No}} \cdot 100 \%
$$

gdzie:

Ns - gospodarstwa $\mathrm{z}$ następcami $\mathrm{w}$ dotychczasowej specjalizacji [liczebność lub udział],

No - gospodarstwa z następcami ogółem [liczebność lub udział].

Powyższy wskaźnik informuje, jaka część następców po przejęciu gospodarstwa zamierza kontynuować dotychczasową specjalizację.

Przyjęto podział badanych gospodarstw na 5 grup, to jest na gospodarstwa posiadające od 11 do 15 krów mlecznych, 16-20 krów, 21-25, 26-50 i powyżej 50. Tak subiektywnie dokonany przez autora podział wynikał $\mathrm{z}$ dwóch przesłanek. Pierwsza $z$ nich ma charakter organizacyjny, gdyż maksymalna liczba utrzymywanych krów wynika $z$ licznych uwarunkowań, w jakich znajduje się gospodarstwo. Druga przesłanka może mieć charakter natury psychologicznej, przyjęto bowiem, że siła stereotypów zachowawczych producentów związana $\mathrm{z}$ trudnościami $\mathrm{w}$ przekraczaniu pewnej psychologicznie granicznej liczby utrzymywanych krów w gospodarstwie może być istotna i może wynikać $\mathrm{z}$ tradycyjnie utrwalonego sposobu myślenia oraz konglomeratu cech osobowych producenta.

W badanych gospodarstwach mlecznych Wisn wynosił średnio 75,2\%. przy czym w I grupie $70,3 \%$, II $76,5 \%$, w III $91,7 \%$ oraz w IV i V po $100 \%$. Można zatem sądzić, że w gospodarstwach z najniższym wskaźnikiem, które utrzymują 11-15 krów mlecznych, duża pracochłonność produkcji i relatywnie niewystarczające efekty dają w porównaniu do innych grup najmniejszy udział 
zadowolonych domowników, zwłaszcza następców, którzy w największej części zamierzają zmienić $\mathrm{w}$ przyszłości specjalizację produkcji. Może to mieć przełożenie na plany inwestycyjne dotyczące produkcji innej niż mleko i co przejawiało się ekstensyfikacją produkcji mleka, a następnie planowaną rezygnacją $\mathrm{z}$ tej produkcji. Badani rolnicy $\mathrm{z}$ grupy II zgodnie twierdzili, że ten rodzaj produkcji wymaga wyjątkowego poświęcenia i dobrowolnej rezygnacji ze swobody życia, gdyż reżim czasowy wymaga samodyscypliny każdego dnia.

Panuje w odczuciu producentów mleka przekonanie, że jeżeli ktoś raz zrezygnuje $z$ produkcji mleka, to już do niej nie wróci. $Z$ badań wynika jednak, że $100 \%$ następców $w$ gospodarstwach utrzymujących powyżej 25 krów chciało w przyszłości $w$ dalszym ciągu produkować mleko $\mathrm{i}$ rozwijać ten rodzaj produkcji. Można uznać, że w tych gospodarstwach efekty są na tyle zachęcające, że rekompensują małą ilość czasu wolnego. Co więcej, stuprocentowy wskaźnik identyfikacji specjalistycznej następców daje między innymi podstawę do przypuszczenia, że w przyszłości rozmiar nakładów inwestycyjnych związany z produkcją mleka w tych gospodarstwach może być największy.

\section{Identyfikacja specjalistyczna następców a inwestycje}

Badania wykazały, że obecność w gospodarstwie następcy w ogóle sprzyjała podejmowaniu inwestycji i zaciąganiu kredytów na ten cel. Ponadto zadłużenie dodatkowo zwiększało się $\mathrm{w}$ przypadku gospodarstw $\mathrm{z}$ następcami $\mathrm{w}$ dotychczasowej specjalności to jest w produkcji mleka (tab. 1).

Tabela 1

Średnie zadłużenie badanych gospodarstw

\begin{tabular}{|l|c|c|c|}
\hline \multirow{2}{*}{ Lata } & \multicolumn{3}{|c|}{ Średnie zadłużenie gospodarstw w tys. zł } \\
\cline { 2 - 4 } & bez następców & $z$ następcami ogółem & $\begin{array}{c}\text { z następcami w produkcji } \\
\text { mleka }\end{array}$ \\
\hline 1997 & 24870 & 35700 & 41800 \\
\hline 1998 & 25970 & 45890 & 45900 \\
\hline 1999 & 28220 & 47750 & 51100 \\
\hline 2000 & 35700 & 55700 & 59000 \\
\hline 2001 & 31240 & 55210 & 57500 \\
\hline
\end{tabular}

Źródlo: badania własne.

Przyjmując średnie zadłużenie w gospodarstwach bez następców za $100 \%$, to $\mathrm{w} 1997$ roku zadłużenie $\mathrm{z}$ następcami ogółem wyniosło $143,5 \%$, a z następcami w produkcji mleka $168,1 \%$. W 1998 roku zadłużenie to wyniosło odpo- 
wiednio 176,7 oraz $176,7 \%$, w 1999 roku 169,2 i $181,1 \%$, w 2000 roku 156,0 i $165,3 \%$, a w 2001 roku 176,7 i $184,1 \%$.

Świadczy to o dodatnim wpływie istnienia następcy w produkcji mleka na inwestycje ogółem z jednej strony, z drugiej zaś o niedoinwestowaniu w tym okresie gospodarstw mlecznych i chęci jak najszybszej zmiany tego stanu wobec rosnących wymogów jakościowych $w$ skupie mleka oraz celowości zwiększenia skali i intensywności produkcji.

\section{Nadwyżka bezpośrednia a wskaźnik identyfikacji specjalistycznej następców}

Posługując się statystyką matematyczną stwierdzono współzmienność między wskaźnikiem identyfikacji następców a wielkością nadwyżki bezpośredniej z produkcji mleka. Wartości współczynnika korelacji brutto wynosiły od 0,2576 w 2000 roku do 0,6261 w 1999 roku. Zwiększenie wskaźnika identyfikacji specjalistycznej następców o $1 \%$ zwiększało nadwyżkę bezpośrednią z produkcji mleka o: $282,8 \mathrm{zł} \mathrm{w} 1997 \mathrm{roku}, 137,4 \mathrm{zł} \mathrm{w} 1998$ roku, 358,2 zł w 1999 roku, $287,0 \mathrm{zł} \mathrm{w} 2000$ roku i 421,2 zł w 2001 roku.

\section{Tabela 2}

Modele regresji prostoliniowej nadwyżki bezpośredniej z produkcji mleka [zł] względem wskaźnika identyfikacji specjalistycznej następców [\%]

\begin{tabular}{|l|c|c|c|c|c|}
\hline \multirow{2}{*}{ Nazwa zmiennej } & \multicolumn{5}{|c|}{ Wartość parametrów w latach } \\
\cline { 2 - 6 } & 1997 & 1998 & 1999 & 2000 & 2001 \\
\hline $\begin{array}{l}\text { Wartość stała } \\
\text { równania }\end{array}$ & 10982 & 25880 & 16910 & 34340 & 16580 \\
\hline $\begin{array}{l}\text { Współczynnik } \\
\text { regresji brutto }\end{array}$ & 282,8028 & 137,4009 & 358,1600 & 287,0300 & 421,19 \\
\hline $\begin{array}{l}\text { Współczynnik } \\
\text { korelacji brutto }\end{array}$ & 0,5127 & 0,3808 & 0,6261 & 0,2576 & 0,4133 \\
\hline $\begin{array}{l}\text { Wartość testu } \\
\text { t-Studenta }\end{array}$ & 7,4663 & 4,8165 & 9,9976 & 3,3191 & 5,6503 \\
\hline $\begin{array}{l}\text { Wartość testu } \\
\text { F. Snedecora }\end{array}$ & 55,2832 & 23,1963 & 99,9519 & 11,0165 & 31,9264 \\
\hline
\end{tabular}

Uwaga: Wartości krytyczne współczynnika korelacji brutto dla poszczególnych poziomów ufności wynoszą: dla $\alpha=0,05 r=0,1519$, a dla $\alpha=0,01 \quad r=0,2081$. Wartości krytyczne testu t-Studenta wynoszą odpowiednio: dla $\alpha=0,05 \mathrm{t}=1,960$, a dla $\alpha=0,01 \mathrm{t}=2,576$. Wartości krytyczne testu $F$ wynoszą: dla $\alpha=0,05 F=3,06$, a dla $\alpha=0,01 F=4,75$.

Żródło: badania własne. 
Najwyższa stała równania w 2000 roku wynosząca 34340 wskazuje na najlepsze ogólne warunki produkcji mleka w tym czasie. Wartość bezwzględna testu t-Studenta we wszystkich latach badań była większa od wartości krytycznej, a zatem wskaźnik identyfikacji specjalistycznej następców był ważnym czynnikiem wpływającym na nadwyżkę bezpośrednią z produkcji mleka. Związek ten nie byl przypadkowy, statystka obserwowana $F$ we wszystkich latach badań była większa niż wartość krytyczna dla $\alpha=0,05$ wynosząca 3,06 .

Średnio za lata 1997-2000 gospodarstwa z następcami w produkcji mleka wypracowały nadwyżkę bezpośrednią w przeliczeniu na 1 krowę mleczną wyższą o:

- $\quad 8,37 \%$ niż gospodarstwa z następcami, którzy po przejęciu gospodarstwa zmienią specjalizację z produkcji mleka,

- $23,59 \%$ w porównaniu do gospodarstw bez następców w ogóle.

Tabela 3

Nadwyżka bezpośrednia w przeliczeniu na 1 krowę mleczną

\begin{tabular}{|l|c|c|c|c|c|}
\hline \multirow{2}{*}{ Nazwa zmiennej } & \multicolumn{5}{|c|}{ Wartośc w latach [zł] } \\
\cline { 2 - 6 } & 1997 & 1998 & 1999 & 2000 & 2001 \\
\hline Gospodarstwa bez następcy & 1945 & 2338 & 2475 & 3530 & 2759 \\
\hline $\begin{array}{l}\text { Gospodarstwa, z następcami, } \\
\text { którzy planują zmianę specja- } \\
\text { lizacji }\end{array}$ & 2229 & 2912 & 3011 & 3702 & 3026 \\
\hline $\begin{array}{l}\text { Gospodarstwa, z następcami, } \\
\text { którzy będą kontynuować } \\
\text { specjalizację }\end{array}$ & 2303 & 2943 & 3107 & 3862 & 3912 \\
\hline
\end{tabular}

Źródło: badania własne.

Przeciętna wartość wskaźnika identyfikacji specjalistycznej następców wynosiła: w 1997 roku 76,0\%, w 1998 roku 72,5\%, w 1999 roku 76,3\%, w 2000 roku 79,2\%, w 2001 roku 72,0\%, a przeciętna wartość nadwyżki bezpośredniej w przeliczeniu na 1 krowę mleczną: w 1997 roku 2272 zl, w 1998 roku 2819 zł, w 1999 roku 2956 zł, w 2000 roku 3739 zł, w 2001 roku 2934 zł.

Warto dodać, że 23,6\% badanych gospodarstw w ogóle nie miało następcy. Spośród istniejących następców około $25 \%$ wyrażało zamiar zmiany specjalizacji mlecznej na inną, udział ten był maksymalny w 2001 roku, kiedy to spadły ceny skupu mleka i producenci musieli poszukiwać możliwości utrzymania opłacalności produkcji na skutek ekstensyfikacji produkcji. Okazało się to działaniem trudnym, zniechęcającym następców do kontynuowania specjalizacji mlecznej. Również rok 1998 był niekorzystny do oceny produkcji mleka przez następców gospodarstw. Wiązało się to $\mathrm{z}$ wprowadzeniem $\mathrm{z}$ dniem 1 stycznia nowej normy PN A-86002 „Mleko surowe do skupu”, na mocy której 
zaczęła obowiązywać klasa ekstra i nowe, wyższe wymagania jakościowe w skupie mleka, wymuszające inwestycje w gospodarstwie oraz dodatkowy wysiłek ekonomiczno-organizacyjny i technologiczny właścicieli badanych gospodarstw specjalistycznych.

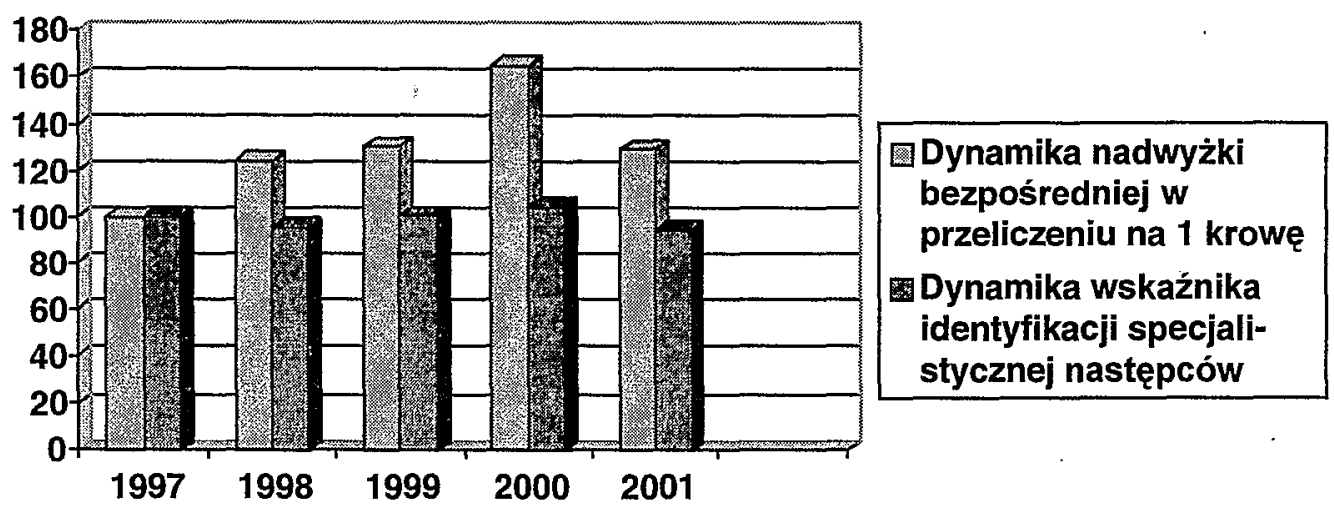

\section{Rysunek 1}

Dynamika nadwyżki bezpośredniej w przeliczeniu na 1 krowę mleczną i wskaźnika identyfikacji specjalistycznej następców [rok $1997=100 \%$ ]

Źródło: badania własne.

\section{Podsumowanie}

Autor zaproponował wprowadzenie wskaźnika identyfikacji specjalistycznej następców, który jest stosunkiem liczby lub udziału gospodarstw $\mathrm{z}$ następcami w dotychczasowej specjalizacji do liczby lub udziału gospodarstw z następcami ogółem w wyrażeniu procentowym.

Badania przeprowadzono w latach 1997-2001 w 157 specjalistycznych gospodarstwach mlecznych makroregionu środkowego.

Wykorzystując rachunek regresji prostoliniowej prostej oraz rachunek korelacji, zaobserwowano istotną statystycznie współzmienność między wskaźnikiem identyfikacji następców a wielkością nadwyżki bezpośredniej z produkcji mleka.

Zwiększenie wskaźnika identyfikacji specjalistycznej następców w 2000 roku wiązało się ze zwiększeniem nadwyżki bezpośredniej z produkcji mleka.

Zaobserwowano ponadto wzrost wskaźnika identyfikacji specjalistycznej następców wraz ze wzrostem liczby utrzymywanych krów w gospodarstwie. 
W latach 1997-2001 w badanych gospodarstwach wskaźnik identyfikacji specjalistycznej następców wahał się od 72,0\% w 2001 roku do 79,2\% w 2000 roku.

\section{Literatura}

KLEPACKI B., 1990: Organizacyjne i ekonomiczne uwarunkowania postępu technologicznego $\mathrm{w}$ gospodarstwach indywidualnych (na przykładzie produkcji roślinnej). Wydawnictwo SGGW, Warszawa.

KLEPACKI B., 1997: Sytuacja ekonomiczna gospodarstw chłopskich w okresie transformacji. Zagadnienia Ekonomiki Rolnej, nr 2-3, Warszawa.

OKULARCZYK S.,.NOVAK T., BRZAZGACZ M., 1996: Nakłady robocizny w produkcji mleka i żywca wołowego. Zagadnienia Ekonomiki Rolnej, nr 2-3, Warszawa.

SKARŻYŃSKA A., POKRZYWA T., AUGUSTYŃSKA - GRZYMEK I., 2002: Produkcja, koszty ekonomiczne i dochody wybranych produktów rolniczych w latach 2000-2001. IERiGŻ, Warszawa.

ZALEWSKI'A., 2000: Gospodarka mleczarska a rynek. IERiGŻ, Warszawa.

\section{The Organisation and Economical and Production Results in Milk Farms with Successors}

\section{Abstract}

The author suggests putting new index - specialist identification successors. It is a quotient of number or participation of farms with the successors in the given specialization to number or participation farms with successors all in all - in the percentage expression.

The research took place in the specialist milk farms of Central Macroregion in the years 1997-2001.

The relationship between quantity of direct surplus from milk production in the farm and the index of specialist identification successors in milk production were observed in 2000 .

The bigger was this surplus, the bigger was the share of successors interested in continuation of milk production after talking over the farm. Moreover it was also observed, that the index of specialist identification successors increased with the increase of the number of cows in the farm.

In the period 1997-2001 in the examined milk farms the quantity of the index of specialist identification successors was changing from $72.0 \%$ in the year 2001 to $79.2 \%$ in 2000 . 